\title{
RBPJ wt Allele
}

National Cancer Institute

\section{Source}

National Cancer Institute. RBPJ wt Allele. NCI Thesaurus. Code C114509.

Human RBPJ wild-type allele is located in the vicinity of 4 p15.2 and is approximately 271

$\mathrm{kb}$ in length. This allele, which encodes recombining binding protein suppressor of hairless

protein, is involved in both transcriptional regulation and intercellular communication.

Mutation of the gene is associated with Adams-Oliver syndrome 3. 